\title{
Sex differences in the brain: a whole body perspective
}

\author{
Geert J. de Vries ${ }^{*}$ and Nancy G. Forger
}

\begin{abstract}
Most writing on sexual differentiation of the mammalian brain (including our own) considers just two organs: the gonads and the brain. This perspective, which leaves out all other body parts, misleads us in several ways. First, there is accumulating evidence that all organs are sexually differentiated, and that sex differences in peripheral organs affect the brain. We demonstrate this by reviewing examples involving sex differences in muscles, adipose tissue, the liver, immune system, gut, kidneys, bladder, and placenta that affect the nervous system and behavior. The second consequence of ignoring other organs when considering neural sex differences is that we are likely to miss the fact that some brain sex differences develop to compensate for differences in the internal environment (i.e., because male and female brains operate in different bodies, sex differences are required to make output/function more similar in the two sexes). We also consider evidence that sex differences in sensory systems cause male and female brains to perceive different information about the world; the two sexes are also perceived by the world differently and therefore exposed to differences in experience via treatment by others. Although the topic of sex differences in the brain is often seen as much more emotionally charged than studies of sex differences in other organs, the dichotomy is largely false. By putting the brain firmly back in the body, sex differences in the brain are predictable and can be more completely understood.
\end{abstract}

Keywords: Brain, Adipose tissue, Bladder, Environment, Gut, Immune system, Kidney, Liver, Muscle, Placenta, Sensory system, Sex difference

\section{Review}

\section{Introduction}

If this were a review about sex differences in skin, bone, kidney, liver, or just about any other peripheral organ, chances are slim that anyone would take offense. Discussing sex differences in the brain puts this paper in a different class altogether and probably for good reasons. We credit our brains for who we are, how we behave, and what we achieve. There seems to be more at stake in believing that brains are different between two groups of people than in believing the same thing about other body parts, which makes the topic of this paper anything but neutral.

In fact, however, sex differences in the nervous system are not really separable from sex differences in other body parts. For example, hormones may affect behavior by acting directly on the brain or more indirectly via a peripheral organ, whose function affects the brain. (Or even more circuitously, such as when hormonal effects

\footnotetext{
* Correspondence: devries@gsu.edu

Neuroscience Institute, Georgia State University, P.O. Box 5030, Atlanta, GA 30302-5030, USA
}

on the body change the way individuals are treated and, hence, their experience and the brain.) The whole body is sexually differentiated, and no organ (the brain included) operates in isolation.

As a "thought experiment," it may be useful to consider a sex-neutral brain hooked up to either a male or female body. Would the brain "know" the sex of the body it was in? How long would this take? Would effects accumulate over time? A few moments reflection will probably lead to the predictions: yes..., not long..., and probably. For starters, there are obvious things like differences in gonadal steroid hormones to which the brain is directly exposed. However, as discussed below, many other factors that affect the brain differ in male versus female bodies based on differences in gene expression, biochemistry, and the structure of peripheral organs.

History justifies a cautious approach when approaching a topic like "brain sex." About a century ago, sex differences in the brain were linked to presumed differences in intelligence and were used to legitimize a diminished role for women in society [1]. Even though 
that interpretation has long since been debunked, unsubstantiated claims about the nature and function of neural sex differences continue to be made and such claims may do serious harm [2-4]. But neglecting sex differences in the brain (or any other body part), or politicizing the discussion of their significance, also has its costs [5].

We believe that ignoring sex differences in the brain, however they arise, compromises best practices in biology and medicine, in some cases with substantiated, negative health effects. A sex difference in a physiological process is one of nature's ways of demonstrating how that process can be modulated. Sex differences in the vulnerability to a disease may similarly reveal factors that are protective in one sex, thereby suggesting strategies to prevent or ameliorate that disease. This is especially true for many neurodevelopmental disorders, where "sex" explains more of the variance than any other known contributing factor [6-10]. In humans, some treatments are known to be more effective in one sex than the other, and optimal drug doses for men and women may differ [11]. We ignore these things at our peril.

Perhaps by viewing sex differences in brain and behavior in the context of the many influences from inside and outside the body, we can see the important topic of neural sex differences in a fresh perspective. In this review, we will discuss research on sex differences in the nervous system and peripheral organs in mammals. We point to several ways that sex differences in the periphery may affect brain function and, finally, touch on how factors outside of the individual may influence the brain.

\section{There are sex differences in the brain}

In the past four decades, many sex differences have been found in brain structure and chemistry [12-15], usually without researchers making spectacular claims as to their significance. Taken together, these findings lead to the inescapable conclusion that male and female brains differ.

The function of some neural sex differences can be understood intuitively. An example that we expand on below is the well-studied sex difference in the number of motoneurons controlling the striated perineal muscles, which mirrors a sex difference in the size of the target muscles themselves. In many cases, however, the functions of neural sex differences are mysterious. We have made the case that although some sex differences may cause differences in function, in other cases sex differences exist to ensure that function is similar in males and females. In other words, some sex differences compensate for physiological differences that if left unchecked may be maladaptive [16]. Both sexes have to eat, drink, breathe, regulate body temperature, and run a host of other homeostatic processes, and nature finds a way to adjust these processes in sex-specific ways. In the end, male brains are in male bodies, and evolution has seen to it that they serve these bodies best, and the same is true for females [17].

Sex differences that perform a compensatory role may become evident when the system is perturbed. A specific example comes from looking at something as seemingly basic as cell death programs in neurons. In response to hypoxia, or other conditions mimicking stroke, neurons die in both sexes of rats and mice. However, the underlying molecular pathways of cell death differ, as becomes clear when pharmacologic or genetic manipulations that inhibit the cell death pathway used by, for example, male cells, only ameliorates the effect of stroke in males $[18,19]$. In this case, an intervention reveals a fundamental sex difference.

Another example concerns one of the most pervasive sex differences: the inactivation of one $\mathrm{X}$ chromosome in every cell of the body in females. Random X inactivation is perhaps the prime example of a sex difference (in this case, a process that happens in all female cells and no male cells) that exists in order to make the sexes more similar (more or less equalizing the dosage of $\mathrm{X}$ chromosome genes). For the most part, nature does a great job in covering up the consequences of this. However, the inactivation of an entire chromosome in each female cell utilizes epigenetic machinery, and the inactivation state must be continually maintained $[20,21]$. There is evidence that this affects the expression of autosomal genes $[22,23]$, presumably because there is a limiting supply of the DNA methyltransferases and histone-modifying enzymes required for the epigenetic changes that underlie the inactivation of an entire chromosome. It is not hard to see how this one event (usually thought of in terms of equalizing males and females) may have ripple effects that result in sex differences elsewhere.

In much the same way that $\mathrm{X}$ chromosome inactivation alters the cellular context, sex differences in peripheral systems also contribute to the different "contexts" in which male and female brains operate. One familiar example concerns gonadal steroid hormones in the general circulation. The peripheral blood of males and females contains different levels of steroid hormones in large part due to differences in production by the gonads. But activity in other organs, e.g., hormone metabolism in the liver or rates of excretion by the kidneys, also contributes to measurable differences in circulating steroid levels $[24,25]$. To the extent that gonadal steroids in circulation differ, most of us are comfortable expecting an effect on the brain, but few of us think about the role the liver or kidneys have played. Although steroids may 
be the most familiar example, many other constituents of blood also reach male and female brains in different levels. Identifying the ways the internal "environment" differs when a brain is in a male versus a female body should provide insight into the development, maintenance, and function of sex differences in the brain, including their role in disease. In this review, we will make the case that a full understanding can only be achieved against the perspective of the entire body (and beyond).

\section{Causes of sex differences in the brain}

For mammals, sex is determined at conception. If the fetus has inherited a Y chromosome, it will develop testes. Hormonal products of the testes, mainly testosterone, then induce the male phenotype by early permanent programming effects (originally called organizational effects) and later transient acute effects, which disappear after withdrawal of the hormones (also called activational effects). In the absence of a $\mathrm{Y}$ chromosome, the fetus develops ovaries, and in the absence of male-like levels of testosterone, the female phenotype emerges. The activating effects of ovarian hormones enhance female characteristics at puberty and beyond.

For much of the latter half of the last century, sex chromosomes were not considered to play an important differentiating role, apart from the crucial first step of directing the early development of the gonads. However, not all sex differences could readily be reversed by altering gonadal hormone levels experimentally, and for some sexually dimorphic traits (e.g., plumage in zebra finches and mammary tissue in wallabies), there was overwhelming evidence that sex differences were hormone-independent [26]. More recently, it has become clear that sex chromosomes play a direct role in establishing sex differences throughout the body, including the brain $[27,28]$. The development of the four core genotype mouse model, in which sex chromosome status and gonad type are inherited independently, has been decisive in showing that some differences depend on chromosomal constitution (XX versus XY) and are gonad independent [28, 29].

Nonetheless, for the large majority of neural sex differences that have been described, sex differences in gonadal steroid hormones seem to play a dominant role. The most parsimonious explanation for how sex differences in the nervous system develop might therefore be that gonadal hormones act directly on the neural tissues that differentiate. This is certainly the case in some instances, but as described below, direct effects of steroids are just one of several possibilities.

\section{Hormones may act on steroid receptors in tissues that differentiate}

In early papers on sexual differentiation, it was de rigueur to include a description of areas that express receptors for gonadal steroid hormones (androgen and estrogen receptors), the implication being that those were the areas most likely to be the direct targets of the differentiating effects of gonadal hormones. It is indeed a good place to start, and in fact, evidence for direct effects of steroids on the regions that differentiate was found in many cases. For example, specific brain regions were shown to express androgen and estrogen receptors during early development [30-34], and the application of testosterone into such regions defeminized the luteinizing hormone surge in female rats $[35,36]$ and masculinized juvenile play behavior and ultrasonic vocalizations of female rats and gerbils, respectively [37, 38]. Blocking hormone action by injecting estrogen receptor mRNA antisense oligonucleotides locally within the hypothalamus also prevented some of the defeminizing and masculinizing effects of testosterone treatment of neonatal female rats [39].

More recently, a direct effect on the brain area in question seems to be assumed more often than proved. If an effect is seen and gonadal steroid receptors are expressed in that region, it is unusual for an investigator to go further, even if the gonadal steroid receptors in question have been demonstrated during adulthood, not during the perinatal critical period.

\section{Hormones may act on steroid receptors in other brain areas that, in turn, influence differentiating areas}

Even when a given brain region expresses the relevant steroid receptors, hormones may act elsewhere to differentiate that area. A good example is the sexually dimorphic projection from the bed nucleus of the stria terminalis (BNST) to the anteroventral periventricular nucleus of the hypothalamus (AVPV). This pathway is 20-fold more dense in male rats and is dependent on early exposure to testosterone [40]. The BNST abundantly expresses androgen and estrogen receptors, and the nucleus is larger in males, so it might be assumed that hormones act at the BNST to influence the outgrowth of BNST axons. To test this, Simerly and colleagues turned to a co-culture system. They first confirmed that the in vivo sex difference was recapitulated in vitro: neurite outgrowth from the BNST was much greater in cocultures of the BNST and AVPV dissected from developing male rat pups than in co-cultures of the BNST and AVPV of females [41]. However, in a mix-and-match experiment, in which the BNST of males (or testosterone-treated females) was co-cultured with the AVPV of females (or vice versa), it was clear that hormone action at the target site (AVPV) determines the size of the projection from the BNST [41]. This kind of mechanism has been appreciated for many years in steroid-dependent development of the periphery. For example, the effects of testosterone on the developing prostate epithelium and mammary gland 
rudiments in male rodents (in one case to cause growth and differentiation, and in the other case, destruction) are mediated indirectly, by hormone action on neighboring cells $[42,43]$.

\section{Hormone action on peripheral structures may in turn influence the nervous system}

Perhaps nowhere has the "site of action" question for an effect of gonadal steroids on the nervous system been pursued as vigorously as it has for the spinal nucleus of the bulbocavernosus (SNB) of rats, and for that system, the answer lies primarily outside of the nervous system. Motoneurons of the SNB innervate striated muscles in the perineal region including the bulbocavernosus and levator ani. These muscles wrap around the base of the penis and contract during erection and ejaculation. In adulthood, male rats have well-developed bulbocavernosus and levator ani muscles and about 200 SNB motoneurons. Females lack the muscles almost entirely and have only about 50 SNB cells [44]. Although best studied in rats, a similar sex difference is seen in other mammals, including humans [45-49].

The sex difference in the rat SNB is completely dependent on androgens around the time of birth [50,51]. Moreover, the SNB motoneurons express androgen receptors in adulthood [44], which was exciting because it suggested that a steroid hormone might act on cells within the central nervous system to cause sex differences (a concept with few direct demonstrations at that time). However, it soon became apparent that for the most conspicuous sex difference associated with the SNB-that of motoneuron number-the site of hormone action was unlikely to be the motoneurons themselves. SNB motoneurons do not express the androgen receptor until after androgens have determined the fate of these cells [52], and androgens can spare SNB motoneurons that themselves do not express the receptor [53]. Instead, the site of hormone action appeared to be the muscles these neurons innervate $[54,55]$. The muscles form in both sexes prenatally but degenerate by apoptosis unless they are exposed to testosterone around birth [56]. Persistence of the muscles is required for SNB survival, perhaps because the muscles produce trophic factors required by the motoneurons [57]. If so, then hormones change something in the body (the perineal muscles) that, in turn, changes something in the central nervous system (motoneuron number in the spinal cord).

Androgen action on striated muscle fibers cannot be the whole explanation for the sex difference in SNB motoneuron number, however, because if androgen receptors are expressed in only striated muscles cells, and no other cell type, this is not sufficient to rescue the SNB system [58]. Other site(s) of hormone action (which could be other cell types in the periphery or in the CNS) presumably also contribute. In adulthood, androgens also act at the target muscle to influence dendritic extent of the motoneurons $[59,60]$, whereas other actions of testosterone on SNB cells (e.g., control of soma size) appear to be direct $[61,62]$.

Because it has been studied in such detail, the SNB is a "poster child" for how hormones can act in the periphery to affect the nervous system [63]. For most of the other examples described below, fewer details are known, but evidence suggests that there are a variety of routes and mechanisms by which the periphery can affect the brain.

\section{Whole body perspective of sexual differentiation of the brain}

In the next paragraphs, we discuss additional examples showing that sexual differentiation of organs and tissues other than the nervous system itself eventually affect neural function or morphology. We do not attempt to cover all possible examples but provide several concrete examples involving an array of organ systems.

\section{Pelvic viscera}

Another consequence of early sexual differentiation is that the pelvic viscera differ in males and females (e.g., seminal vesicles, epididymis, and prostate in males; uterus and fallopian tubes in females). This, perhaps not surprisingly, is accompanied by sex differences in innervation. The viscera receive parasympathetic, sympathetic, and sensory innervation via the pelvic, hypogastric, and pudendal nerves [64], and for all three modalities, sex differences have been described (either in the number of innervating cells or fibers or the pattern of innervation; e.g., [65-67]). For example, sensory innervation of the perineum provided by the pudendal nerve differs in males and females. The cell bodies providing this innervation, which reside in the dorsal root ganglia, are more numerous in male rats than in females [68, 69]. Although details are lacking regarding how this sex difference develops, it may be due to greater neuronal cell death in females, as in the SNB [69].

Perhaps less obvious are sex differences in the innervation of peripheral structures that are present in both sexes, such as the bladder, which receives sympathetic innervation from the hypogastric nerve. When Nadelhaft and McKenna applied a retrograde tracer to the stump of the severed hypogastric nerve of rats, they found almost four times as many labeled preganglionic sympathetic neurons in the spinal cord in males than in females [70]. A similar sex difference was seen in guinea pigs [67]. When one keeps in mind that these sympathetic neurons do not exist in isolation, but themselves receive innervation, the possibilities for cascading effects on ever higher levels of the nervous system are clear. 
Brain areas involved in micturition (emptying the bladder) [71] show higher levels of activation in men than in women during conscious control of the pelvic muscles that control urine flow [72]. The bladder has sex differences not just in innervation (above and [73]) but in neurotransmitter receptors [74], structure of the bladder wall [75], and size of the external urethral sphincter muscle [76]. As there are also sex differences in pathophysiology, e.g., women are more likely to show overactive bladder activity coupled with incontinence than are men $[77,78]$, and boys are more likely to show nocturnal enuresis (bedwetting) than girls $[79,80]$, full understanding of interactions among sex differences in the brain and body may be required for developing optimal treatments of these conditions in males and females.

\section{Adipose tissue}

Men and women have differences in adipose tissue distribution. Women tend to accumulate subcutaneous, femoral, and gluteus fat whereas men deposit fat within the abdomen [81]. Adipose tissue is an endocrinesignaling organ, producing a number of peptide and steroid hormones (e.g., leptin, adiponectin, inflammatory cytokines, and estrogens) some of which reach the brain and act on receptors there (see [82-84] for review). Interestingly, these signals may differ, on average, in males and females because of the differences in the metabolic profile of subcutaneous versus visceral fat. For example, the increased visceral fat seen in obese men compared to obese women contributes to elevated inflammatory cytokines in men [85].

Although gonadal steroid hormones are known to play a role in fat deposition, recent research also suggests a gonad-independent role for genes on the sex chromosomes. Mice with two $\mathrm{X}$ chromosomes, regardless of whether they have testes or ovaries, have more fat [86]. This effect is most clearly seen in mice of the four core genotype model mentioned above: after removal of the gonads, $\mathrm{XX}$ females have twice the adipose tissue as $\mathrm{XY}$ females and are much more likely to develop fatty liver [86]. Although a similar experiment cannot be done in humans, abnormalities in sex chromosome numbers as in Klinefelter (XXY males) and Turner syndrome (X0 females) are associated with abnormalities in adipose tissue distribution $[87,88]$.

Thus, both gonadal steroids and sex chromosomes may influence the brain via effects on adipose tissue. In addition, adipose tissue receives sympathetic innervation, and this innervation differs by sex and fat pad [89]. It is not known whether sympathetic neurons innervating adipose tissue become different in response to their sexually dimorphic targets (in analogy to sex differences in the SNB motoneurons that innervate the bulbocavernosus muscle described earlier) or, conversely, if differential innervation plays a role in causing the sex differences in body fat distribution [90].

\section{Liver}

The liver secretes steroid-binding proteins and contains enzymes that metabolize circulating gonadal steroids $[24,25,91,92]$. These enzymes may influence the level of gonadal steroids differently in males and females. To some extent, we have already factored in the action of the liver (albeit, usually without thinking about it) when we measure differences in circulating hormone levels. We may think that differences are caused by different levels of hormone secretion by the gonads, but these levels are the result of local production and metabolisms by various organs, the liver being one of the most important. Moreover, following an acute treatment with the "same" dose of steroid, males and females may be subject to differences in biologically active steroid that reaches the brain due to sex difference in liver function. Different function of the liver would also affect metabolism of environmental estrogens such as phytoestrogens, which would again affect steroid-responsive systems in the brain differently in the two sexes.

Although we do not normally think of the liver or adipose tissue as being very sexually dimorphic organ systems, the expression of $72 \%$ of all genes surveyed in the liver and $68 \%$ of adipose tissue genes differs between male and female mice [93]. These percentages are much larger than one would expect based on the modest sex differences in the overt form and functions of liver and adipose tissue. To gain some perspective, however, the liver supplies the majority of yolk proteins in egg-laying species, and ultrastructural sex differences in the liver are required to accommodate this massive protein production in females [94]. Although the requirement for a sexually dimorphic liver is less obvious in species bearing live young, the maternal liver also synthesizes proteins important for fetal development in mammals [94].

The liver also metabolizes most drugs, leading to sex differences in pharmacodynamics and pharmacokinetics [25]. A good example of a drug with lower clearance in women than in men is the sleep aid, zolpidem (trade name: Ambien) [95]. Sex-specific dose recommendations for this drug were issued in 2013 by the U.S. Food and Drug Administration, 20 years after it came to market [96], and zolpidem is currently the only drug with different recommended doses for men and women. In general, however, women have more adverse drug reactions than men [11,97], and there are likely many more drugs on the market that should have sex-specific dosing. When the Food and Drug Administration of the U.S.A. reviewed new drug applications between 1995 and 2000, only half included analysis by sex, and of those, 6-7 \% 
showed a large $(>40 \%)$ difference in pharmacokinetics between men and women [98].

\section{Peripheral immune system}

Sex differences in immune activation are observed in response to the same stimulus $[99,100]$ and may underlie well-established sex biases in immune-related diseases. Women have a higher incidence of most autoimmune diseases [101, 102] and may also have increased responses to tumors and infections. Differences persist when lymphocytes harvested from men and women are stimulated in vitro [103], which is important because it rules out potentially confounding effects of the cells being in a male versus a female body. Differences in immune activation or inflammation in males and females during critical periods of development have been linked to sex-specific effects on brain functions such as learning and memory, locomotion, and emotional regulation [104]. A recent meta-analysis concludes that many of the sex differences in immunological response are attributable to the immune-regulatory effects of sex steroid hormones [100]. However, the sex chromosomes may also play an important role, as illustrated by the next example.

Multiple sclerosis (MS) is a neurodegenerative disease with a whole-body explanation involving multiple peripheral organs and contributions from both gonadal steroids and sex chromosomes. In MS, a patient's immune system attacks components of the myelin sheaths encircling axons, and the disease is more prevalent in women than in men. Females are also more susceptible in a mouse model of MS (experimental autoimmune encephalomyelitis), and the explanation for this is distributed across body parts. To induce the MS-like disorder, mice receive injections of myelin basic protein and immuneboosting agents near lymph nodes. A sex difference is already found in the initial induction phase of the disease, such that male mice have fewer lymph node immune cells and fewer reactive cells that produce inflammatory cytokines than do females in response to inoculation with the myelin basic protein [105]. If this sex difference in the induction phase is taken out of the equation by transferring myelin basic protein-specific $\mathrm{T}$ lymphocytes from females into mice of both sexes, males still show protection to disease onset [106], and one mechanism appears to be increased production of antiinflammatory cytokines by male spleen cells. Thus, the periphery presents the brains of males and females with different stimuli given the same disease trigger.

Although numerous studies have proposed protective roles for gonadal steroid hormones in MS (reviewed in [107]), and sex steroids are being tested in MS clinical trials, there are also likely to be important direct chromosomal effects. Using the four core genotype mice in the mouse model for MS mentioned above, XY lymph node cells show a smaller immune response in the induction phase regardless of the gonad type of the donor [108]. Interestingly, however, when the sex of immune system cells is held constant (e.g., XX immune system in an $\mathrm{XX}$ or $\mathrm{XY}$ animal), mice with an $\mathrm{XY}$ nervous system show more severe pathology [109]. This may be related to the clinical observation that although MS is more prevalent in woman, men with MS have faster disease progression [110, 111].

Depression, a stress-related disorder, is also more common in women than in men $[112,113]$. In most cases, we would look to the brain to explain a difference in susceptibility to depression, but recent findings suggest it could be linked to individual or sex-based differences in activation of the peripheral immune system. An increase in the number of white blood cells is reported in men with major depression [114]. When male mice are subjected to a social stressor, some subsequently exhibit depressive-like behavior, whereas others are resilient. Hodes and colleagues noted that there were significant differences in the peripheral immune response to stress between mice that subsequently were susceptible or resilient. Surprisingly, resilience could be "transplanted": susceptible mice receiving a bone marrow transplant (and, hence, peripheral immune system) from resilient mice themselves became resilient [115]. This suggests that the peripheral response to a stressor may be an important factor determining the onset of depression. Although this study included only males, previously reported sex differences in the peripheral immune response to stressors suggest that in some cases depression and anxiety disorders may be traced to the periphery.

In addition to effects of the peripheral immune system on the brain, recent work suggests that the brain itself uses elements of immune or inflammatory signaling in the process of sexual differentiation. For example, prostaglandins-best known for their roles in inflammation-are required for masculinization of copulatory behavior and dendritic spine density in the preoptic area of the hypothalamus in rats [116]. Moreover, masculinization can be blocked by neonatally preventing brain prostaglandin synthesis [116] or by inhibiting microglia, the innate immune cells of the brain and producers of prostaglandins [117].

\section{Gut}

Gene expression in the small intestine and colon differs in male and female mice and does so even before weaning $[118,119]$. In addition, adult males and females housed in the same environment and eating the same food exhibit differences in the gut microbiota (the collection of microorganisms living symbiotically in our intestines) [120]. These differences can account for differences in behavior or susceptibility to disease. In a 
mouse strain that is susceptible to type 1 diabetes, for example, females are more often affected than males, but the sex difference disappears when the mice are raised germ free (i.e., in the absence of a microbiome) [120]. This suggests a role for the microbiota in the sex difference in diabetes susceptibility. To test this more directly, Markle and colleagues transferred the gut microbiota from adult males to juvenile females of the diabetes-susceptible strain. The female recipients' microbiota, hormone levels, and serum metabolites were all altered, such that they were now diabetes resistant [120]. Thus, the microorganisms that live in us and on us may differ by sex and cause differences in disease.

Recent work also suggests that the microbiota has acute as well as programming effects on the brain and behavior. For example, mice treated with valproic acid on gestational day 11 are well-established animal models for autism. These mice have reduced social interactions and increased markers of gut inflammation, but both changes are found in males only [121]. The same valproic acid treatment also significantly alters the composition of bacteria comprising the gut microbiota, and social behavior correlates with the levels of metabolites (lactate, butyrate, and acetate) generated by these microorganisms [122]. Although quite interesting, this evidence is indirect because many factors in addition to gut microbiota may be affected by gestational exposure to valproic acid. More direct evidence was obtained very recently by showing that germ-free mice were less sociable and did not show the typical preference for investigating novel mice [123]. Colonizing germ-free mice with a microbiota at day 21 only partially normalized social responses in adulthood [123], suggesting that microbiota must be present even earlier for completely normal social behavior. This study also found stronger effects of early exposure to microbiota in males than in females.

The gut microbiota has various ways to exert its influence on the brain. The best substantiated of these is signaling via the vagus nerve, which can transmit information related to local changes in the gut wall to the brain. But gut microbiota can also signal via the bloodstream, e.g., by changing levels of free fatty acids, neurotransmitter precursors, and inflammatory cytokines produced by immune cells in the gut wall in response to specific gut pathogens [124]. A very intriguing possibility is that the microbiota can also influence circulating levels of steroids such as testosterone [120], which would of course interact with programming and acute effects of steroids produced by the gonads.

\section{Kidney}

The role of the kidney is to remove the waste products of metabolism while also maintaining water balance. Vasopressin, a peptide hormone synthesized in the hypothalamus and released by the posterior pituitary, is crucial in conserving water loss (hence its other name-antidiuretic hormone). The vasopressin $V_{2}$ receptor $\left(\mathrm{V}_{2} \mathrm{R}\right)$ mediates the antidiuretic effect of vasopressin on the kidney, and female mice express about twice as much $V_{2} R$ mRNA and more than twice as much $V_{2} R$ protein than do males [125]. This difference probably results from the location of the $V_{2} R$ gene on the $\mathrm{X}$ chromosome. Although most $\mathrm{X}$ chromosomal genes are expressed at comparable levels in males and females due to random $\mathrm{X}$ inactivation, this inactivation is not complete. In humans, up to $15 \%$ of X chromosomal genes escape inactivation to varying degrees [126], and of these, the $\mathrm{V}_{2} \mathrm{R}$ gene has among the highest levels of escape [126]. In mice, the higher levels of $V_{2} R$ translate to a greater sensitivity: treatment with the same dose of desmopressin, a synthetic vasopressin agonist, reduces urine production and increases urine osmolarity to a greater extent in females than in males [125]. A similar difference has been reported for humans $[127,128]$, in which desmopressin treatment of nocturia, an abnormal urge to urinate during the night, was more likely to cause hyponatremia (abnormally low sodium concentration in the blood, usually due to increased water retention) in women than in men. Based on these findings, the authors suggested that women should be treated with half to one fourth of the dose used for men [128], although this suggestion has not been adopted.

Under normal conditions, the sex difference in kidney $\mathrm{V}_{2} \mathrm{R}$ expression does not appear to cause major physiological differences, but if the system is stressed, differences in osmoregulation occur that can affect the brain. For example, female marathon runners and endurance swimmers have a higher risk of cerebral edema related to hypoosmolarity than do male runners $[129,130]$. This appears to be related to an increase in vasopressin release during the run [131], which may provoke a stronger kidney response in women than in men, increasing their risk for acute hyponatremia. In addition to causing differences in brain pathology, sex differences in $V_{2} R$ expression may also be related to sexual differentiation of the hypothalamic neurons that produce vasopressin. For example, the supraoptic nucleus is bigger and has larger vasopressin neurons in male than in female rats [132] and also produces more vasopressin mRNA [133]. These differences are suggested to relate to sex differences in overall body size [132], but it is possible that they are, at least in part, the result of a compensatory response to the lower levels of kidney $\mathrm{V}_{2} \mathrm{R}$ expression in males.

\section{Sensory systems}

Even given the exact same environment, males and females may experience that environment differently, due to sex differences in sensory systems. Taste, pain/touch, vision, and olfactory sensitivities differ between males 
and females, and there is evidence for both acute and programming effects of gonadal steroids on these sex differences.

For example, rats show sex differences in behavioral taste sensitivity to sodium chloride solutions, and sex differences in gustatory processing of the same-strength salt solution can be measured in electrophysiological recordings of the chorda tympani nerve [134]. In humans, women have a higher density of fungiform papillae on the tongue than do men [135], and differences in taste sensitivity have been reported between the sexes as well as across the menstrual cycle in women [136].

Over 40 years ago, estrogens were shown to increase the size of the pudendal nerve receptive field and the sensitivity of cutaneous receptors in the perineum of rats, making female rats more sensitive to stimulation around the vagina at the time of estrus [137]. Touch sensitivity also varies in women during the menstrual cycle in regions one would not think of as sexual, such as the cornea [138]. Pain thresholds [139] and response to common analgesics [140] vary by sex in both humans and in animal models, as does degree of pain experienced in a number of clinical conditions. For example, in a mouse model of multiple sclerosis, only females exhibit neuropathic pain (sensitivity to mechanical, cold, and heat stimulation), even when motor dysfunction does not differ between the sexes [141]. Similarly, women with osteoarthritis have significantly more pain than men, even when controlling for variables such as depression, anxiety, pain catastrophizing, social support, and physical activity [142]. Whether this is due to sex differences in the periphery or in neural processing is not known.

Sex differences in olfactory processing have received more attention than those in other sensory modalities, perhaps because the most common experimental animals (mice and rats) are highly olfactory. Wellestablished sex differences are found in the detection and response to socially relevant urinary odors in mice. Some sex differences persist even if all animals are gonadectomized [143], or gonadectomized and treated with an estrogen [144], indicating programming/organizational effects of hormones, or possibly a direct sex chromosomal effect, on the processing of olfactory cues. Using expression of the immediate early gene cFos as a measure of neuronal activity, a sex difference in the neural response to an olfactory stimulus can be seen as early as the vomeronasal epithelium (i.e., the primary sensory neuron detecting pheromones) [145]. While the authors considered the possibility that this sex difference is due to centrifugal inputs from the central nervous system to vomeronasal neurons [145], a recent paper pushes the envelope by showing that in the female mouse, vomeronasal sensory neurons respond to male-specific urinary proteins in estrus, but not in the diestrus phase of the cycle [146]. Because the response of the sensory detectors was studied after they were removed from the nose and dissociated in culture, centrifugal influences should have been absent. The finding was, moreover, traced to the ability of high levels of progesterone (characteristic of diestrus) to block the functioning of vomeronasal neurons that respond to male urinary proteins, while not affecting those that respond to a predator odor [146].

Not all sex differences in sensory systems are due to hormones. Sex differences in color discrimination have been linked to genetic sex because genes for retinal photopigments reside on the $\mathrm{X}$ chromosome. Owing to a double dose of $\mathrm{X}$ chromosome genes, some women have up to four different X-linked photo color pigment alleles, and these women perceive an increased number of distinct colors [147, 148]. Conversely, by having only a single set of $\mathrm{X}$ chromosomal alleles, males are much more sensitive to deleterious mutations in photopigment genes and have a higher incidence of color blindness [149]. Thus, gonadal steroids and sex chromosomes can alter the reception of primary sensory cues, literally changing the perceived world.

\section{A "Sexorganome"?}

The idea that sex differences in biological systems are interdependent was recently proposed for networks of genes by Arnold and Lusis, who introduced the term "the sexome" [150]. They point out that the function of every cell in the body is the product of an intricate network of interactions among all the different molecules that make up a cell and define the sexome as "the sum of all sex-specific and sex-biased modulatory interactions that operate within [these] network[s]" [150]. Although individual sex differences in gene expression may be small, in the aggregate, these differences may importantly affect function or may prevent sex differences in other cases [150].

The idea of the sexome likely applies to every tissue in the body. As alluded to above, transcriptome studies show pervasive sex differences in gene expression in peripheral tissues. The factors that induce sex bias in gene networks are the same as those that induce sex bias in neural networks and behavior, i.e., programming and acute effects of gonadal steroids, sex chromosomes, and the environment. These factors probably affect some nodes in the network (e.g., genes with estrogen-response elements in the promoter region) more than others. As these genes form part of a network, however, changes in the expression of one gene will affect the expression of all others in the network.

Although the sexome was originally formulated to explain the working of gene networks, it may be possible to take a more "macro" view of the sexome, where nodes in the networks are organs rather than genes. For example, 
sex differences in the function of the liver will affect the composition of the blood, and sex differences in the composition of the blood may affect the function of all other tissues in the body, including the brain. Just as the sexome proposed by Arnold and Lusis is the aggregate of gene expression differences, bodies are aggregates of organs influencing each other via functional ties, which could be thought of as the "sexorganome" (Fig. 1). And just as sex affects some genes more than others, the factor "sex" will affect some organs in more obvious ways than others. Figure 1 is by no means encyclopedic and merely represents some of the interactions between the brain and organs discussed in this paper, leaving out most interactions between those organs. We would be surprised if, once the data are in, there would be any organ left that could not be added to the figure.

This perspective may be useful in thinking about the implications of a sex difference, wherever in the body. Up to now, we have glossed over the fact that there is a huge variation in the magnitude of sex differences depending on brain region, organ, tissue, etc. For some measures, there is very little overlap between the sexes (such as number of SNB motoneurons or size of the projection from the BNST to AVPV discussed above), whereas for other differences the overlap between the sexes is great (such as the size of the supraoptic nucleus, discussed above as well). In addition, the magnitude of a given sex difference is often context-dependent and varies depending on age, the presence of physical or emotional stressors during development and in adulthood, etc. [15]. In seasonally reproducing species, time of year may be a factor. To the extent that organs influence each other, the effects of factors on the size of sex differences in one organ will reverberate in the form and function of other organs.

\section{Beyond the body}

Although most of the interactions described above take place within a single body, there are also more circuitous routes by which sex can affect the brain and behavior. We give just a few examples here.

\section{Placenta}

The placenta is comprised of cells derived from both the mother and the fetus and is therefore sex-specific (only male fetuses have a placenta containing male cells). Maternal diet affects gene expression in the placenta and does so differently depending on whether the

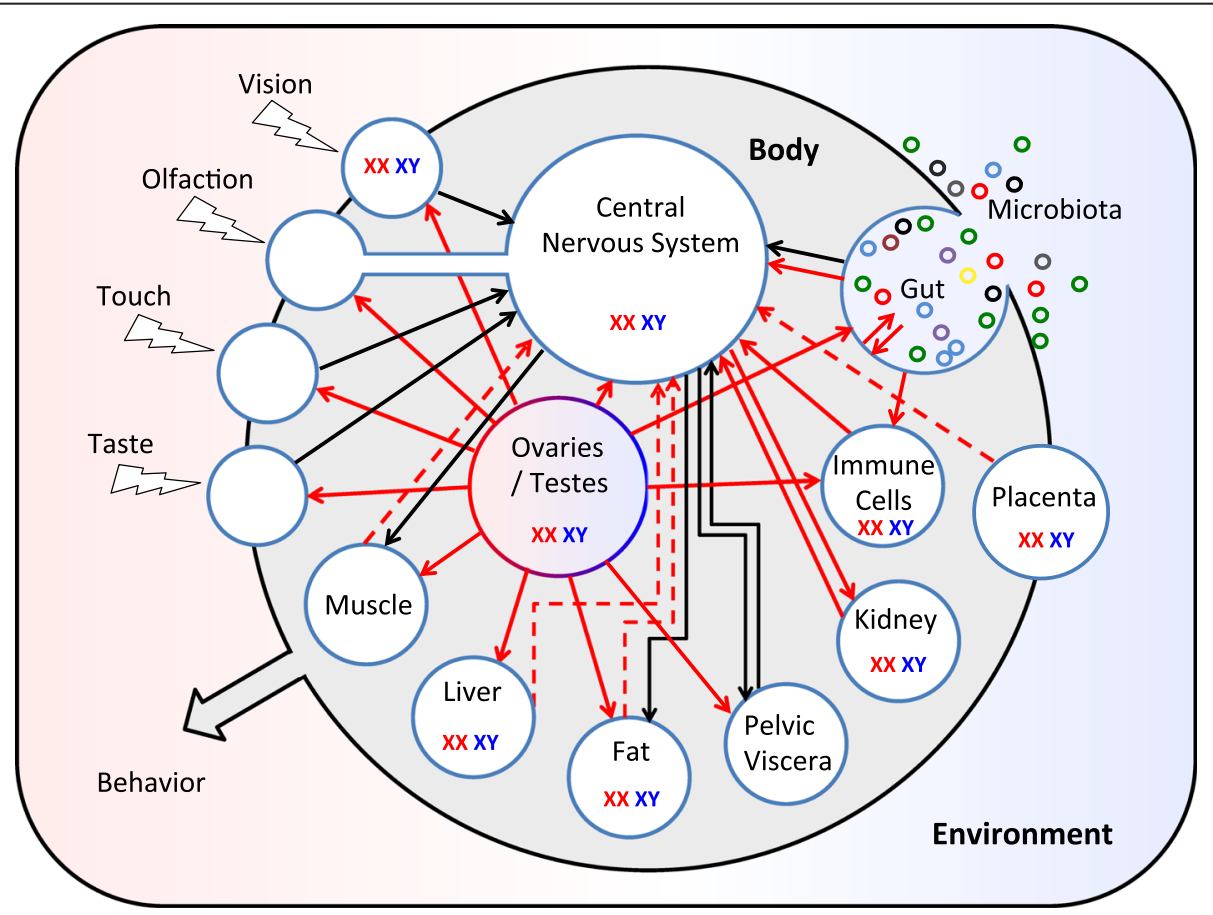

Fig. 1 Sex differences in peripheral influences on the central nervous system. The CNS is embedded in a sexually differentiated body that is embedded in an environment, which may interact with the body in a manner that varies by sex. This diagram represents interactions between the central nervous system and sex differences elsewhere in the body that are discussed in this paper; other interactions undoubtedly occur. Solid arrows indicate a sex influence from one organ on another. Dashed arrows indicate an influence inferred from circumstantial evidence, but not yet demonstrated. Black arrows indicate neural communication; red arrows indicate humoral communication. "XX XY" indicates organs in which sex chromosome complement has a demonstrated effect; in most cases, it is not known whether the effect is mediated within that organ or indirectly via effects on other organs. The small colored circles in the upper right are the many species of microorganisms living commensally in our gut or on our skin 
placenta is male or female [151]. There are also sexspecific responses of the placenta to stressors $[152,153]$, which would be expected to influence how male and female fetuses experience perturbations in utero, and may affect later brain function. When pregnant female rats were subjected to a stressor during early gestation, male but not female offspring exhibited adverse effects on stress responsivity, anhedonia, and response to selective serotonin reuptake inhibitors in adulthood [154]. The placenta appears to be the site of action for these sexspecific responses because the early prenatal stress causes elevations of immune response genes, including interleukin- 6 and interleukin- $1 \beta$, specifically in male placentas, and the stress phenotype in males could be blunted by blocking this response [155]. Here is a scenario, then, where a stressor experienced by one animal (the mother) influences brain development of the offspring in a sex-dependent manner and does so via effects on a tissue that is outside of the "body proper" and neither entirely fetal nor maternal!

\section{Muscles and teeth}

Overall, muscle mass is much larger in males of many mammalian species. In humans, which are less dimorphic than many other primates, total skeletal muscle mass is about $60 \%$ greater in men than in women [156]. As far as we know, this is not normally accompanied by differences in motoneuron number but could affect the brain and behavior more indirectly. Canine tooth size is also up to $400 \%$ larger in the males of some anthropoid primates [157], and this difference is at least partially due to prenatal androgens $[158,159]$. It is not hard to imagine that endowing an animal with greater overall size, greater muscle mass, and fourfold larger canines might affect its behavior. Whether it is feedback the individual gets about his/her own strength or the reaction of other individuals, the brain will not fail to notice. Currently, however, we really do not know where in the brain to look for such effects.

Because complicated questions sometimes yield to simpler model systems, worms may be useful here. William Mowrey, Douglas Portman, and colleagues recently conducted the worm equivalent of the thought experiment proposed above. They examined locomotor behavior in male Caenorhabditis elegans roundworms with a "female" nervous system and "female" worms with a male nervous system (female is in quotations here because although $C$. elegans come in two sexes, they are males and hermaphrodites-modified females capable of self-fertilization). Sexual dimorphism in C. elegans is cell autonomous and depends on expression of the tra-1 gene [160]. Thus, by expressing or repressing tra-1 in specific cell types, one can mix and match the sex of various tissues within the same worm.
Locomotion in male and hermaphrodite C. elegans involves sine-wave-like body undulations that differ along several dimensions. By examining locomotion in male worms with a hermaphrodite nervous system (and vice versa), one dimension (body-wave frequency) was shown to be determined completely by the sex of the nervous system. In fact, body-wave frequency could be sexreversed by reversing only the sex of sensory neurons [161]. Locomotor velocity, on the other hand, was not affected by sex of the nervous system but could be masculinized in hermaphrodites with male muscle cells. Neural plus muscle sex reversal came close to completely sex-reversing locomotion, but something was still missing. The authors hypothesize that the missing piece is related to biomechanics, i.e., the different overall size of male and hermaphrodite bodies interacting with the substrate along which they move [161]. Thus, the "sex" of even this very basic behavior-sine wave locomotion in worms-is distributed among sensory neurons, muscles, and the interaction of the individual with the environment.

As the worm example suggests, and as researchers studying the biomechanics of locomotion have long known, if brains are wired up to different bodies, similar neural output can have different consequences [162]; conversely, to generate similar behaviors, the nervous system residing in male and female bodies may have to compensate by giving different commands. The interaction of the size and shape of the body with the medium it travels through points to the final variable we consider here-the environment.

\section{The environment-"It takes a village..."}

One very important indirect effect of gonadal hormones on the brain is likely mediated via effects on the genitalia which, in humans at least, change the way we are treated from the moment of birth, indeed, before birth, if parents know the sex of the fetus [163]. Later in life, being categorized as "male" or "female" may continue to have a profound influence on the social input the individual receives, with consequences for the brain.

These effects are not limited to humans. Male rats are licked more frequently by their mothers than are females. Variations in maternal licking affect later sexual behavior [164], the number and morphology of motoneurons in the SNB $[165,166]$, and several measures in the brain (for example, $[167,168])$. Differential treatment of male and female pups by the mother is caused by differences in the urine, due to male pheromones produced under influence of testosterone by the preputial glands [169]. Therefore, the chain of events seems to be that sex chromosomes cause differences in the gonads, which cause differences in testosterone production, causing a different constitution of the urine, which affects the behavior of another 
individual (the mother), and thereby the developing nervous system and behavior of the individual. Somatosensory contact by the mother also affects juvenile play behavior in her offspring and does so in a sex-dependent manner [170]. In turn, juvenile play alters social and sexual interactions in adulthood, suggesting another complex cascade of effects. To make matters more interesting, interactions are not limited to those with conspecifics-as mentioned above, sex differences in the microbiota, for example, indicate that our treatment by, or "attractiveness" to, other species also varies by sex.

One justified criticism of our field has been that results are often presented as though sex is hardwired, that having a Y chromosome, and therefore testes, sets in motion a process towards maleness that is unavoidable. Well, it depends on how you look at it. On the one hand, different treatment from others (whether "others" are caregivers or bacteria) is presumably a response to some physical or behavioral sex difference(s) (genitalia, physique, gait, activity level, biochemistry of intestines, chemicals in urine, to name a few), which is a manifestation of programming and acute effects of hormones and differential expression of sex chromosomal genes. In other words, the impetus for sexual differentiation is the $Y$ chromosome and differences in sex steroids, but the routes via which these factors exert their effects are more circuitous than is (often tacitly) implied in the literature. For humans, with extensive social interactions and long development times, this means that there are plenty of opportunities to override or, alternatively, magnify the initial "program."

\section{Conclusion}

\section{Back to the future}

In the early days, Frank Beach famously resisted the conclusion that differences in sexual behavior in male and female rodents were caused by differences in the brain, instead pointing to feedback from the genitalia as an obvious possible mediator (for discussion, see [171]). Although later research, including that by Beach himself [172], proved that one can masculinize behavior without corresponding changes to the genitalia [173, 174], the early Beach was on to something. The realization that hormones have direct actions on the brain was exciting, and in our embrace of this idea, the pendulum may have swung too far. Over the last 50 years, research in the field of neural sex differences has only rarely considered a role for other organs. With a single-minded focus on the brain, this organ may appear to have special access to the whisperings of sex chromosomes or sex steroids. All organs are sexually differentiated to some degree, and keeping the whole body in mind opens the aperture to consider novel mechanisms and pathways for the development of normal sex differences, as well as the mechanisms underlying neurological disorders and diseases that show sex differences in onset, course of disease, and morbidity.

\section{Abbreviations}

AVPV: Anteroventral periventricular nucleus of the hypothalamus; BNST: Bed nucleus of the stria terminalis; CNS: Central nervous system; MS: Multiple sclerosis; SNB: Spinal nucleus of the bulbocavernosus; $V_{2} R$ : Vasopressin $V_{2}$ receptor.

\section{Competing interests}

The authors declare that they have no competing interests.

\section{Authors' contributions}

GD and NF each contributed to the literature review and the writing of this manuscript. Both authors read and approved the final manuscript.

\section{Acknowledgements}

Work from the authors' laboratories is supported by grants from the National Institutes of Health R01-MH047538 and R01-MH068482.

Received: 30 June 2015 Accepted: 28 July 2015

Published online: 15 August 2015

\section{References}

1. Swaab DF, Hofman MA. Sexual differentiation of the human brain. A historical perspective. Prog Brain Res. 1984;61:361-74.

2. Jordan-Young R, Rumiati Rl. Hardwired for sexism? Approaches to sex/gender in neuroscience. Neuroethics. 2012;5(3):305-15.

3. Fine $\mathrm{C}$. Is there neurosexism in functional neuroimaging investigations of sex differences? Neuroethics. 2013;6(2):369-409.

4. Fine C, Jordan-Young R, Kaiser A, Rippon G. Plasticity, plasticity, plasticity... and the rigid problem of sex. Trends Cogn Sci. 2013;17(11):550-1.

5. Klein SL, Schiebinger L, Stefanick ML, Cahill L, Danska J, de Vries GJ, et al. Opinion: sex inclusion in basic research drives discovery. Proc Natl Acad Sci U S A. 2015;112(17):5257-8.

6. Werling DM, Geschwind DH. Sex differences in autism spectrum disorders. Curr Opin Neurol. 2013;26(2):146-53.

7. Burd L, Li Q, Kerbeshian J, Klug MG, Freeman RD. Tourette syndrome and comorbid pervasive developmental disorders. J Child Neurol. 2009;24(2):170-5.

8. Eme RF. Sex differences in child-onset, life-course-persistent conduct disorder. A review of biological influences. Clin Psychol Rev. 2007;27(5):607-27.

9. Holden C. Sex and the suffering brain. Science. 2005;308(5728):1574-7.

10. Landgren M, Kjellman B, Gillberg C. Attention deficit disorder with developmental coordination disorders. Arch Dis Child. 1998;79(3):207-12.

11. Miller MA. Gender-based differences in the toxicity of pharmaceuticals - The Food and Drug Administration's perspective. Int J Toxicol. 2001;20(3):149-52.

12. De Vries GJ, Simerly RB. Anatomy, development, and function of sexually dimorphic neural circuits in the mammalian brain. In: Pfaff DW, Arnold AP, Etgen AM, Fahrbach SE, Moss RL, Rubin RT, editors. Hormones, brain, and behavior volume IV development of hormone-dependent neuronal systems. San Diego: Academic; 2002. p. 137-91.

13. McCarthy MM, De Vries GJ, Forger NG. Sexual differentiation of the brain: mode, mechanisms, and meaning. In: Pfaff DW, Arnold AP, Etgen AM, Fahrbach SE, Rubin RT, editors. Hormones, brain and behavior, vol. 3. 2nd ed. San Diego: Academic; 2009. p. 1707-44.

14. Morris JA, Jordan CL, Breedlove SM. Sexual differentiation of the vertebrate nervous system. Nat Neurosci. 2004;7(10):1034-9.

15. Forger NG, De Vries GJ, Breedlove SM. Sexual differentiation of brain and behavior. In: Plant TM, Zelenik AJ editors. Knobil and Neill's physiology of reproduction, Fourth Edition. Amsterdam, Elsevier; 2015. p. 2109-2155

16. De Vries GJ. Sex differences in adult and developing brains: compensation, compensation, compensation. Endocrinology. 2004;145(3):1063-8.

17. de Vries GJ, Södersten P. Sex differences in the brain: the relation between structure and function. Horm Behav. 2009;55(5):589-96.

18. Yuan M, Siegel C, Zeng Z, Li J, Liu F, McCullough LD. Sex differences in the response to activation of the poly (ADP-ribose) polymerase pathway after experimental stroke. Exp Neurol. 2009;217(1):210-8.

19. Hagberg $H$, Wilson MA, Matsushita $H$, Zhu CL, Lange M, Gustavsson M, et al. PARP-1 gene disruption in mice preferentially protects males from perinatal brain injury. J Neurochem. 2004;90(5):1068-75. 
20. Csankovszki G, Nagy A, Jaenisch R. Synergism of Xist RNA, DNA methylation, and histone hypoacetylation in maintaining $X$ chromosome inactivation. J Cell Biol. 2001;153(4):773-83.

21. Yang F, Deng X, Ma W, Berletch JB, Rabaia N, Wei G, et al. The IncRNA Firre anchors the inactive $X$ chromosome to the nucleolus by binding CTCF and maintains H3K27me3 methylation. Genome Biol. 2015;16.

22. Wijchers PJ, Festenstein RJ. Epigenetic regulation of autosomal gene expression by sex chromosomes. Trends Genet. 2011;27(4):132-40.

23. Arnold AP. The end of gonad-centric sex determination in mammals. Trends Genet. 2012;28(2):55-61.

24. Mode A, Gustafsson JA. Sex and the liver - a journey through five decades. Drug Metab Rev. 2006;38(1-2):197-207.

25. Waxman DJ, Holloway MG. Sex differences in the expression of hepatic drug metabolizing enzymes. Mol Pharmacol. 2009;76(2):215-28.

26. Arnold AP. Genetically triggered sexual differentiation of brain and behavior. Horm Behav. 1996;30(4):495-505.

27. Arnold AP. The organizational-activational hypothesis as the foundation for a unified theory of sexual differentiation of all mammalian tissues. Horm Behav. 2009:55(5):570-8.

28. Arnold AP, Chen XQ. What does the "four core genotypes" mouse model tell us about sex differences in the brain and other tissues? Front Neuroendocrinol. 2009;30(1):1-9.

29. De Vries GJ, Rissman EF, Simerly RB, Yang LY, Scordalakes EM, Auger CJ, et al. A model system for study of sex chromosome effects on sexually dimorphic neural and behavioral traits. J Neurosci. 2002;22(20):9005-14.

30. DonCarlos $L L$, Handa RJ. Developmental profile of estrogen receptor mRNA in the preoptic area of male and female neonatal rats. Brain Res Dev Brain Res. 1994;79(2):283-9.

31. Vito CC, Baum MJ, Bloom C, Fox TO. Androgen and estrogen receptors in perinatal ferret brain. Jo Neurosci. 1985;5(2):268-74.

32. Vito CC, Fox TO. Androgen and estrogen receptors in embryonic and neonatal rat brain. Brain Res. 1981;254(1):97-110.

33. Friedman WJ, McEwen BS, Toran-Allerand CD, Gerlach JL. Perinatal development of hypothalamic and cortical estrogen receptors in mouse brain: methodological aspects. Brain Res. 1983;313(1):19-27.

34. McAbee MD, DonCarlos LL. Ontogeny of region-specific sex differences in androgen receptor messenger ribonucleic acid expression in the rat forebrain. Endocrinology. 1998;139(4):1738-45.

35. Barraclough CA, Gorski RA. Evidence that the hypothalamus is responsible for androgen-induced sterility in the female rat. Endocrinology. 1961;68:68-79.

36. Hayashi S, Gorski RA. Critical exposure time for androgenization by intracranial crystals of testosterone propionate in neonatal female rats. Endocrinology. 1974;94(4):1161-7.

37. Meaney MJ, McEwen BS. Testosterone implants into the amygdala during the neonatal-period masculinize the social play of juvenile female rats. Brain Res. 1986;398(2):324-8.

38. Holman SD, Hutchison JB. Effects of intracranial androgen on the development of masculine ultrasonic vocalizations in the Mongolian gerbil (Meriones unguiculatus). J Endocrinol. 1985;107(3):355-64.

39. McCarthy MM, Schlenker EH, Pfaff DW. Enduring consequences of neonatal treatment with antisense oligodeoxynucleotides to estrogen-receptor messenger-ribonucleic-acid on sexual-differentiation of rat-brain. Endocrinology. 1993;133(2):433-9.

40. Hutton LA, Gu GB, Simerly RB. Development of a sexually dimorphic projection from the bed nuclei of the stria terminalis to the anteroventral periventricular nucleus in the rat. J Neurosci. 1998;18(8):3003-13.

41. Ibanez MA, Gu GB, Simerly RB. Target-dependent sexual differentiation of a limbic-hypothalamic neural pathway. J Neurosci. 2001;21(15):5652-9.

42. Cunha GR, Lung B. The possible influence of temporal factors in androgenic responsiveness of urogenital tissue recombinants from wild-type and androgen-insensitive (Tfm) mice. J Exp Zool. 1978;205(2):181-93.

43. Drews U, Drews U. Regression of mouse mammary gland anlagen in recombinants of Tfm and wild-type tissues: testosterone acts via the mesenchyme. Cell. 1977;10(3):401-4.

44. Breedlove SM, Arnold AP. Hormone accumulation in a sexually dimorphic motor nucleus of the rat spinal cord. Science. 1980;210(4469):564-6.

45. Forger NG, Breedlove SM. Sexual dimorphism in human and canine spinal cord: role of early androgen. Proc Natl Acad Sci U S A. 1986;83(19):7527-31.

46. Wee BEF, Clemens LG. Characteristics of the spinal nucleus of the bulbocavernosus are influenced by genotype in the house mouse. Brain Res. 1987:424(2):305-10.
47. Ueyama T, Mizuno N, Takahashi O, Nomura S, Arakawa H, Matsushima R. Central distribution of efferent and afferent components of the pudendal nerve in macaque monkeys. J Comp Neurol. 1985;232(4):548-56.

48. Ulibarri C, Popper P, Micevych PE. Motoneurons dorsolateral to the centra canal innervate perineal muscles in the Mongolian gerbil. J Comp Neurol. 1995;356(2):225-37.

49. Forger NG, Frank LG, Breedlove SM, Glickman SE. Sexual dimorphism of perineal muscles and motoneurons in spotted hyenas. J Comp Neurol. 1996;375(2):333-43.

50. Breedlove SM, Arnold AP. Sexually dimorphic motor nucleus in the rat lumbar spinal cord: response to adult hormone manipulation, absence in androgen-insensitive rats. Brain Res. 1981;225(2):297-307.

51. Breedlove SM, Arnold AP. Hormonal-control of a developing neuromuscular system.2. Sensitive periods for the androgen-induced masculinization of the rat spinal nucleus of the bulbocavernosus. J Neurosci. 1983;3(2):424-32.

52. Jordan $\mathrm{CL}$, Padgett $\mathrm{B}$, Hershey J, Prins G, Arnold A. Ontogeny of androgen receptor immunoreactivity in lumbar motoneurons and in the sexually dimorphic levator ani muscle of male rats. J Comp Neurol. 1997;379(1):88-98.

53. Freeman LM, Watson NV, Breedlove SM. Androgen spares androgeninsensitive motoneurons from apoptosis in the spinal nucleus of the bulbocavernosus in rats. Horm Behav. 1996;30(4):424-33.

54. Fishman RB, Breedlove SM. Local perineal implants of anti-androgen block masculinization of the spinal nucleus of the bulbocavernosus. Brain Res Dev Brain Res. 1992;70(2):283-6.

55. Sengelaub DR, Forger NG. The spinal nucleus of the bulbocavernosus: firsts in androgen-dependent neural sex differences. Horm Behav. 2008;53(5):596-612.

56. Jacob DA, Bengston CL, Forger NG. Effects of Bax gene deletion on muscle and motoneuron degeneration in a sexually dimorphic neuromuscular system. J Neurosci. 2005;25(23):5638-44.

57. Forger NG, Roberts SL, Wong V, Breedlove SM. Ciliary neurotrophic factor maintains motoneurons and their target muscles in developing rats. J Neurosci. 1993;13(11):4720-6.

58. Niel L, Shah AH, Lewis GA, Mo K, Chatterjee D, Fernando SM, et al. Sexual differentiation of the spinal nucleus of the bulbocavernosus is not mediated solely by androgen receptors in muscle fibers. Endocrinology. 2009;150(7):3207-13.

59. Rand MN, Breedlove SM. Androgen alters the dendritic arbors of SNB motoneurons by acting upon their target muscles. J Neurosci. 1995;15(6):4408-16.

60. Huguenard AL, Fernando SM, Monks DA, Sengelaub DR. Overexpression of androgen receptors in target musculature confers androgen sensitivity to motoneuron dendrites. Endocrinology. 2011;152(2):639-50.

61. Monks DA, Vanston CM, Watson NV. Direct androgenic regulation of calcitonin gene-related peptide expression in motoneurons of rats with mosaic androgen insensitivity. J Neurosci. 1999;19(13):5597-601.

62. Watson NV, Freeman LM, Breedlove SM. Neuronal size in the spinal nucleus of the bulbocavernosus: direct modulation by androgen in rats with mosaic androgen insensitivity. J Neurosci. 2001;21(3):1062-6.

63. Swift-Gallant A, Niel L, Monks DA. Turning sex inside-out: peripheral contributions to sexual differentiation of the central nervous system. Biol Sex Differ. 2012;3.

64. de Groat WC, Nadelhaft I, Milne RJ, Booth AM, Morgan C, Thor K. Organization of the sacral parasympathetic reflex pathways to the urinary bladder and large intestine. J Auton Nerv Syst. 1981;3(2-4):135-60.

65. Greenwood D, Coggeshall RE, Hulsebosch CE. Sexual dimorphism in the numbers of neurons in the pelvic ganglia of adult rats. Brain Res. 1985;340(1):160-2.

66. Suzuki Y, Arai Y. Laterality associated with sexual dimorphism in the volume of the mouse hypogastric ganglion. Exp Neurol. 1986;94(1):241-6.

67. McLachlan EM. The components of the hypogastric nerve in male and female guinea-pigs. J Auton Nerv Syst. 1985;13(4):327-42.

68. McKenna KE, Nadelhaft I. The organization of the pudendal nerve in the male and female rat. J Comp Neurol. 1986;248(4):532-49.

69. Mills AC, Sengelaub DR. Sexually dimorphic neuron number in lumbosacral dorsal-root ganglia of the rat - development and steroid regulation. J Neurobiol. 1993:24(11):1543-53.

70. Nadelhaft I, McKenna KE. Sexual dimorphism in sympathetic preganglionic neurons of the rat hypogastric nerve. J Comp Neurol. 1987;256(2):308-15.

71. Fowler CJ, Griffiths D, de Groat WC. The neural control of micturition. Nat Rev Neurosci. 2008;9(6):453-66. 
72. Seseke S, Baudewig J, Kallenberg K, Ringert RH, Seseke F, Dechent P. Gender differences in voluntary micturition control - an fMRI study. Neuroimage. 2008:43(2):183-91

73. Yamaguchi K, Kobayashi M, Kato T, Akita K. Origins and distribution of nerves to the female urinary bladder: new anatomical findings in the sex differences. Clin Anat. 2011;24(7):880-5.

74. Patra PB, Patra S. Sex differences in the physiology and pharmacology of the lower urinary tract. Current Urology. 2012;6(4):179-88.

75. Ponglowhapan S, Church DB, Khalid M. Differences in the proportion of collagen and muscle in the canine lower urinary tract with regard to gonadal status and gender. Theriogenology. 2008;70(9):1516-24.

76. Cruz Y, Downie JW. Sexually dimorphic micturition in rats: relationship of perineal muscle activity to voiding pattern. Am J Physiol Regul Integr Comp Physiol. 2005;289(5):R1307-18.

77. Temml C, Heidler S, Ponholzer A, Madersbacher S. Prevalence of the overactive bladder syndrome by applying the International Continence Society definition. Eur Urol. 2005;48(4):622-7.

78. Sekido N, Hinotsu S, Kawai K, Shimazui T, Akaza H. How many uncomplicated male and female overactive bladder patients reveal detrusor overactivity during urodynamic study? Int J Urol. 2006;13(10):1276-9.

79. Özkan S, Durukan E, Iseri E, Gürocak S, Maral I, Bumin MA. Prevalence and risk factors of monosymptomatic nocturnal enuresis in Turkish children. Indian J Urol. 2010;26(2):200.

80. Chiozza M, Bernardinelli L, Caione P, Del Gado R, Ferrara P, Giorgi P, et al. An Italian epidemiological multicentre study of nocturnal enuresis. Br J Urol. 1998;81(s3):86-9.

81. Jensen MD. Adipose tissue and fatty acid metabolism in humans. J R Soc Med. 2002;95:3-7.

82. Guerre-Millo M. Adipose tissue hormones. J Endocrinol Investig. 2002;25(10):855-61.

83. Trayhurn P, Beattie JH. Physiological role of adipose tissue: white adipose tissue as an endocrine and secretory organ. Proc Nutr Soc. 2001;60(3):329-39.

84. Simpson ER. Sources of estrogen and their importance. J Steroid Biochem Mol Biol. 2003;86(3-5):225-30

85. Bloor ID, Symonds ME. Sexual dimorphism in white and brown adipose tissue with obesity and inflammation. Horm Behav. 2014;66(1):95-103.

86. Chen X, McClusky R, Chen J, Beaven SW, Tontonoz P, Arnold AP, et al. The number of $X$ chromosomes causes sex differences in adiposity in mice. Plos Genetics. 2012;8(5):e1002709.

87. Bojesen A, Kristensen K, Birkebaek NH, Fedder J, Mosekilde L, Bennett P, et al. The metabolic syndrome is frequent in Klinefelter's syndrome and is associated with abdominal obesity and hypogonadism. Diabetes Care. 2006;29(7):1591-8.

88. Van PL, Bakalov VK, Bondy CA. Rapid communication - monosomy for the $\mathrm{X}$-chromosome is associated with an atherogenic lipid profile. J Clin Endocrinol Metab. 2006;91(8):2867-70

89. Adler ES, Hollis JH, Clarke IJ, Grattan DR, Oldfield BJ. Neurochemical characterization and sexual dimorphism of projections from the brain to abdominal and subcutaneous white adipose tissue in the rat. J Neurosci. 2012;32(45):15913-21.

90. Fliers E, Kreier F, Voshol PJ, Havekes LM, Sauerwein HP, Kalsbeek A, et al. White adipose tissue: getting nervous. J Neuroendocrinol. 2003;15(11):1005-10.

91. Kottler ML, Dang CD, Salmon R, Counis R, Degrelle H. Effect of testosterone on regulation of the level of sex steroid-binding protein messenger rna in monkey (Macaca fascicularis) liver. J Mol Endocrinol. 1990;5(3):253-8.

92. Waxman DJ. Regulation of liver-specific steroid metabolizing cytochromep450 - cholesterol 7-alpha-hydroxylase, bile-acid 6-beta-hydroxylase, and growth hormone-responsive steroid-hormone hydroxylases. J Steroid Biochem Mol Biol. 1992;43(8):1055-72.

93. Yang $X$, Schadt EE, Wang $S$, Wang $H$, Arnold AP, Ingram-Drake L, et al. Tissue-specific expression and regulation of sexually dimorphic genes in mice. Genome Res. 2006;16(8):995-1004.

94. Roy AK, Chatterjee B. Sexual dimorphism in the liver. Annu Rev Physiol. 1983:45:37-50.

95. Greenblatt DJ, Harmatz JS, Singh NN, Steinberg F, Roth T, Moline ML, et al. Gender differences in pharmacokinetics and pharmacodynamics of zolpidem following sublingual administration. J Clin Pharmacol. 2014;54(3):282-90.

96. FDA News Release, 2013: FDA requiring lower recommended dose for certain sleep drugs containing zolpidem. [http://www.fda.gov/newsevents/ newsroom/pressannouncements/ucm334798.htm]. Accessed 3 Aug 2015
97. Rademaker M. Do women have more adverse drug reactions? Am J Clin Dermatol. 2001;2(6):349-51.

98. Anderson GD. Sex and racial differences in pharmacological response: where is the evidence? Pharmacogenetics, pharmacokinetics, and pharmacodynamics. J Womens Health. 2005;14(1):19-29.

99. Furman D, Hejblum BP, Simon N, Jojic V, Dekker CL, Thiebaut $R$, et al. Systems analysis of sex differences reveals an immunosuppressive role for testosterone in the response to influenza vaccination. Proc Natl Acad Sci U S A. 2014;111(2):869-74.

100. Mirandola L, Wade R, Verma R, Pena C, Hosiriluck N, Figueroa JA, et al. Sex-driven differences in immunological responses: challenges and opportunities for the immunotherapies of the third millennium. Int Rev Immunol. 2015;34(2):134-42.

101. Beeson PB. Age and sex associations of 40 autoimmune-diseases. Am J Med. 1994;96(5):457-62.

102. Whitacre CC, Reingold SC, O'Looney PA, Task Force Gender Multiple Sclerosis A. Biomedicine - a gender cap in autoimmunity. Science. 1999;283(5406):1277-8

103. Bouman A, Schipper M, Heineman MJ, Faas MM. Gender difference in the non-specific and specific immune response in humans. Am J Reprod Immunol. 2004;52(1):19-26.

104. Bale TL. Neuroendocrine and immune influences on the CNS: it's a matter of sex. Neuron. 2009;64(1):13-6.

105. Kim SH, Voskuhl RR. Decreased IL-12 production underlies the decreased ability of male lymph node cells to induce experimental autoimmune encephalomyelitis. J Immunol. 1999;162(9):5561-8.

106. Voskuhl RR, PitchekianHalabi H, MacKenzieGraham A, McFarland HF, Raine CS. Gender differences in autoimmune demyelination in the mouse: implications for multiple sclerosis. Ann Neurol. 1996:39(6):724-33.

107. Spence RD, Voskuhl RR. Neuroprotective effects of estrogens and androgens in CNS inflammation and neurodegeneration. Front Neuroendocrinol. 2012;33(1):105-15.

108. Smith-Bouvier DL, Divekar AA, Sasidhar M, Du S, Tiwari-Woodruff SK, King JK, et al. A role for sex chromosome complement in the female bias in autoimmune disease. J Exp Med. 2008;205(5):1099-108.

109. Du S, Itoh N, Askarinam S, Hill H, Arnold AP, Voskuhl RR. XY sex chromosome complement, compared with $X X$, in the CNS confers greater neurodegeneration during experimental autoimmune encephalomyelitis. Proc Natl Acad Sci U S A. 2014;111(7):2806-11.

110. Voskuhl RR, Gold SM: Sex-related factors in multiple sclerosis susceptibility and progression. Nature Reviews Neurology 2012, 8(5):255-263.

111. Antulov R, Weinstock-Guttman B, Cox JL, Hussein S, Durfee J, Caiola C, et al. Gender-related differences in MS: a study of conventional and nonconventional MRI measures. Multiple Sclerosis 2009, 15(3):345-354.

112. Bale TL. Stress sensitivity and the development of affective disorders. Horm Behav. 2006;50(4):529-33.

113. Altemus M. Sex differences in depression and anxiety disorders: potential biological determinants. Horm Behav. 2006;50(4):534-8.

114. Maes M, Vanderplanken M, Stevens WJ, Peeters D, Declerck LS, Bridts CH, et al. Leukocytosis, monocytosis and neutrophilia - hallmarks of severe depression. J Psychiatr Res. 1992;26(2):125-34.

115. Hodes GE, Pfau ML, Leboeuf M, Golden SA, Christoffel DJ, Bregman D, et al. Individual differences in the peripheral immune system promote resilience versus susceptibility to social stress. Proc Natl Acad Sci U S A. 2014;111(45):16136-41

116. Amateau SK, MCCarthy MM. Induction of PGE(2) by estradiol mediates developmental masculinization of sex behavior. Nat Neurosci. 2004;7(6):643-50.

117. Lenz KM, Nugent BM, Haliyur R, McCarthy MM. Microglia are essential to masculinization of brain and behavior. J Neurosci. 2013;33(7):2761-72.

118. Sugiyama MG, Hobson L, Agellon AB, Agellon LB. Visualization of sex-dimorphic changes in the intestinal transcriptome of Fabp2 gene-ablated mice. J Nutrigenet Nutrigenomics. 2012;5(1):45-55

119. Steegenga WT, Mischke M, Lute C, Boekschoten MV, Pruis MGM, Lendvai A, et al. Sexually dimorphic characteristics of the small intestine and colon of prepubescent C57BL/6 mice. Biol Sex Differ. 2014;5.

120. Markle JGM, Frank DN, Mortin-Toth S, Robertson CE, Feazel LM, Rolle-Kampczyk $U$, et al. Sex differences in the gut microbiome drive hormone-dependent regulation of autoimmunity. Science. 2013;339(6123):1084-8. 
121. de Theije CGM, Koelink PJ, Korte-Bouws GAH, da Silva SL, Korte SM, Olivier $B$, et al. Intestinal inflammation in a murine model of autism spectrum disorders. Brain Behav Immun. 2014;37:240-7.

122. de Theije CGM, Wopereis H, Ramadan M, van Eijndthoven T, Lambert J, Knol J, et al. Altered gut microbiota and activity in a murine model of autism spectrum disorders. Brain Behav Immun. 2014;37:197-206.

123. Desbonnet L, Clarke G, Shanahan F, Dinan TG, Cryan JF. Microbiota is essential for social development in the mouse. Mol Psychiatry. 2014;19(2):146-8.

124. Cryan JF, Dinan TG. Mind-altering microorganisms: the impact of the gut microbiota on brain and behaviour. Nat Rev Neurosci. 2012;13(10):701-12.

125. Liu J, Sharma N, Zheng W, Ji H, Tam H, Wu X, et al. Sex differences in vasopressin $V(2)$ receptor expression and vasopressin-induced antidiuresis. Am J Physiol Renal Physiol. 2011;300(2):F433-40.

126. Carrel L, Willard HF. X-inactivation profile reveals extensive variability in $X$-linked gene expression in females. Nature. 2005;434(7031):400-4.

127. Juul KV, Bichet DG, Nielsen S, Norgaard JP. The physiological and pathophysiological functions of renal and extrarenal vasopressin V2 receptors. Am J Physiol Renal Physiol. 2014;306(9):F931-40.

128. Juul KV, Klein BM, Sandstrom R, Erichsen L, Norgaard JP. Gender difference in antidiuretic response to desmopressin. Am J Physiol Renal Physiol. 2011;300(5):F1116-22.

129. Wagner S, Knechtle B, Knechtle P, Ruest CA, Rosemann T. Higher prevalence of exercise-associated hyponatremia in female than in male open-water ultra-endurance swimmers: the 'Marathon-Swim' in Lake Zurich. Eur J Appl Physiol. 2012;112(3):1095-106.

130. Rosner MH, Kirven J. Exercise-associated hyponatremia. Clin J Am Soc Nephrol. 2007;2(1):151-61.

131. Siegel AJ, Verbalis JG, Clement S, Mendelson JH, Mello NK, Adner M, et al. Hyponatremia in marathon runners due to inappropriate arginine vasopressin secretion. Am J Med. 2007;120(5):461.e411-467.

132. Madeira MD, Sousa N, Cadeteleite A, Lieberman AR, Paulabarbosa MM. The supraoptic nucleus of the adult-rat hypothalamus displays marked sexual dimorphism which is dependent on body-weight. Neuroscience. 1993;52(3):497-513.

133. Taylor PV, Veenema AH, Paul MJ, Bredewold R, Isaacs S, de Vries GJ. Sexually dimorphic effects of a prenatal immune challenge on social play and vasopressin expression in juvenile rats. Biol Sex Differ. 2012;3(1):15-5.

134. Curtis KS, Contreras RJ. Sex differences in electrophysiological and behavioral responses to $\mathrm{NaCl}$ taste. Behav Neurosci. 2006;120(4):917-24.

135. Bartoshuk LM, Duffy VB, Miller IJ. PTC/PROP tasting - anatomy, psychophysics, and sex effects. Physiol Behav. 1994;56(6):1165-71.

136. Prutkin J, Duffy VB, Etter L, Fast K, Gardner E, Lucchina LA, et al. Genetic variation and inferences about perceived taste intensity in mice and men. Physiol Behav. 2000;69(1-2):161-73.

137. Kow LM, Pfaff DW. Effects of estrogen treatment on the size of receptive field and response threshold of pudendal nerve in the female rat. Neuroendocrinology. 1973;13(4):299-313.

138. Riss $B$, Binder $S$, Riss $P$, Kemeter $P$. Corneal sensitivity during the menstrual cycle. Br J Ophthalmol. 1982;66(2):123-6.

139. Greenspan JD, Craft RM, LeResche L, Arendt-Nielsen L, Berkley KJ, Fillingim $\mathrm{RB}$, et al. Studying sex and gender differences in pain and analgesia: a consensus report. Pain. 2007;132:\$26-45.

140. Loyd DR, Murphy AZ. The neuroanatomy of sexual dimorphism in opioid analgesia. Exp Neurol. 2014;259:57-63.

141. Rahn EJ, lannitti T, Donahue RR, Taylor BK. Sex differences in a mouse model of multiple sclerosis: neuropathic pain behavior in females but not males and protection from neurological deficits during proestrus. Biol Sex Differ. 2014;5:4.

142. Tonelli SM, Rakel BA, Cooper NA, Angstom WL, Sluka KA. Women with knee osteoarthritis have more pain and poorer function than men, but similar physical activity prior to total knee replacement. Biol Sex Differ. 2011;2:12.

143. Baum MJ, Keverne EB. Sex difference in attraction thresholds for volatile odors from male and estrous female mouse urine. Horm Behav. 2002;41(2):213-9.

144. Sorwell KG, Wesson DW, Baum MJ. Sexually dimorphic enhancement by estradiol of male urinary odor detection thresholds in mice. Behav Neurosci. 2008;122(4):788-93.

145. Halem HA, Baum MJ, Cherry JA. Sex difference and steroid modulation of pheromone-induced immediate early genes in the two zones of the mouse accessory olfactory system. J Neurosci. 2001;21(7):2474-80.
146. Dey S, Chamero P, Pru JK, Chien MS, Ibarra-Soria X, Spencer KR, et al. Cyclic regulation of sensory perception by a female hormone alters behavior. Cell. 2015;161(6):1334-44.

147. Jameson KA, Highnote SM, Wasserman LM. Richer color experience in observers with multiple photopigment opsin genes. Psychon Bull Rev. 2001;8(2):244-61.

148. Rodríguez-Carmona M, Sharpe LT, Harlow JA, Barbur JL. Sex-related differences in chromatic sensitivity. Vis Neurosci. 2008;25(3):433-40.

149. Sharpe LT, Stockman A, Jagle H, Nathans J. Opsin genes, cone photopigments, color vision, and color blindness. In: Sharpe LT, Gegenfurtner KR, editors. Color vision: from genes to perception. Cambridge: Cambridge University Press; 1999. p. 3-52.

150. Arnold AP, Lusis AJ. Understanding the sexome: measuring and reporting sex differences in gene systems. Endocrinology. 2012;153(6):2551-5.

151. Mao J, Zhang X, Sieli PT, Falduto MT, Torres KE, Rosenfeld CS. Contrasting effects of different maternal diets on sexually dimorphic gene expression in the murine placenta. Proc Natl Acad Sci U S A. 2010;107(12):5557-62.

152. Clifton VL. Sex and the human placenta: mediating differential strategies of fetal growth and survival. Placenta. 2010;31:S33-9.

153. Gabory A, Roseboom TJ, Moore T, Moore LG, Junien C. Placental contribution to the origins of sexual dimorphism in health and diseases: sex chromosomes and epigenetics. Biol Sex Differ. 2013;4.

154. Mueller BR, Bale TL. Sex-specific programming of offspring emotionality after stress early in pregnancy. J Neurosci. 2008;28(36):9055-65.

155. Bronson G. Critical periods in human-development. Br J Med Psychol. 1962:35(2):127.

156. Wang ZM, Heo M, Lee RC, Kotler DP, Withers RT, Heymsfield SB. Muscularity in adult humans: proportion of adipose tissue-free body mass as skeletal muscle. Am J Hum Biol. 2001;13(5):612-9.

157. Plavcan JM, Ruff CB. Canine size, shape, and bending strength in primates and carnivores. Am J Phys Anthropol. 2008;136(1):65-84.

158. Zingeser MR, Phoenix $\mathrm{CH}$. Metric characteristics of the canine dental complex in prenatally androgenized female rhesus monkeys (Macaca mulatta). Am J Phys Anthropol. 1978;49(2):187-92.

159. Heikkinen T, Harila V, Tapanainen JS, Alvesalo L. Masculinization of the eruption pattern of permanent mandibular canines in opposite sex twin girls. Am J Phys Anthropol. 2013;151(4):566-72.

160. Zarkower D. Somatic sex determination (February 10, 2006). WormBook, ed The C elegans Research Community, WormBook, doi/101895/ wormbook1841, http://www.wormbook.org/chapters/www_ somaticsexdeterm/somaticsexdeterm.html.

161. Mowrey WR, Bennett JR, Portman DS. Distributed effects of biological sex define sex-typical motor behavior in Caenorhabditis elegans. J Neurosci. 2014;34(5):1579-91.

162. Chiel HJ, Beer RD. The brain has a body: adaptive behavior emerges from interactions of nervous system, body and environment. Trends Neurosci. 1997;20(12):553-7.

163. Fine C. Delusions of gender: how our minds, society and neurosexism create a difference. New York: W.W. Norton Company; 2010. 2010.

164. Moore CL. Maternal contributions to the development of masculine sexualbehavior in laboratory rats. Dev Psychobiol. 1984;17(4):347-56.

165. Moore $\mathrm{CL}$, Dou H, Juraska JM. Maternal stimulation affects the number of motor neurons in a sexually dimorphic nucleus of the lumbar spinal cord. Brain Res. 1992;572(1-2):52-6.

166. Lenz KM, Graham MD, Parada M, Fleming AS, Sengelaub DR, Monks DA. Tactile stimulation during artificial rearing influences adult function and morphology in a sexually dimorphic neuromuscular system. Dev Neurobiol. 2008;68(4):542-57.

167. Bredy TW, Grant RJ, Champagne DL, Meaney MJ. Maternal care influences neuronal survival in the hippocampus of the rat. Eur J Neurosci. 2003;18(10):2903-9.

168. Liu D, Diorio J, Day JC, Francis DD, Meaney MJ. Maternal care, hippocampal synaptogenesis and cognitive development in rats. Nat Neurosci. 2000;3(8):799-806.

169. Moore CL. Sex differences in urinary odors produced by young laboratory rats (Rattus norvegicus). J Comp Psychol. 1985;99(3):336-41.

170. Edelmann M, Wolfe C, Scordalakes EM, Rissman EF, Tobet S. Neuronal nitric oxide synthase and calbindin delineate sex differences in the developing hypothalamus and preoptic area. Dev Neurobiol. 2007;67(10):1371-81. 
171. Wallen K. The organizational hypothesis: reflections on the 50th anniversary of the publication of Phoenix, Goy, Gerall, and Young (1959). Horm Behav. 2009:55(5):561-5.

172. Beach FA. Effects of gonadal hormones on urinary behavior in dogs. Physiol Behav. 1974;12(6):1005-13.

173. Olsen KL. Induction of male mating behavior in androgen-insensitive (tfm) and Normal (King-Holtzman) male rats: effect of testosterone propionate, estradiol benzoate, and dihydrotestosterone. Horm Behav. 1979;13(1):66-84.

174. Goy RW, Bercovitch FB, McBrair MC. Behavioral masculinization is independent of genital masculinization in prenatally androgenized female rhesus macaques. Horm Behav. 1988;22(4):552-71.

\section{Submit your next manuscript to BioMed Central and take full advantage of:}

- Convenient online submission

- Thorough peer review

- No space constraints or color figure charges

- Immediate publication on acceptance

- Inclusion in PubMed, CAS, Scopus and Google Scholar

- Research which is freely available for redistribution 